\title{
PEMANFAATAN GOOGLE APPS DI ERA LITERASI DIGITAL PADA SISWA SEKOLAH DASAR
}

\author{
Bahrul Ulum ${ }^{1}$, Frendy Aru Fantiro², \& Mochamad Novi Rifa'i ${ }^{3}$ \\ 1. Pendidikan Guru Sekolah Dasar, Universitas Muhammadiyah Malang \\ bahrul@umm.ac.id (085236323442) \\ 2. Pendidikan Guru Sekolah Dasar, Universitas Muhammadiyah Malang \\ frendy_aru@umm.ac.id
3. Pendidikan Guru Sekolah Dasar, Universitas Muhammadiyah Malang novirifai@umm.ac.id

\begin{abstract}
ABSTRAK
Tujuan penelitian ini untuk mendeskripsikan pemanfaatan Google Apps di era literasi digital pada siswa Sekolah Dasar (SD). Metode penelitian menggunakan penelitian deskriptif kualitatif dengan teknik pengumpulan data menggunakan studi kepustakaan. Literasi digital merupakan kemampuan kemampuan penggunaan teknologi informasi dari perangkat digital secara efektif efisien dalam berbagai konteks kehidupan sehari-hari. Salah satu upaya literasi digital adalah pemanfaatan teknologi informasi menggunakan Google Apps for education yang telah disediakan oleh perusahaan mesin pencari google untuk segenap komponen pendidikan disekolah. Dengan memanfaatkan Google Apps dalam proses pembelajaran yang dapat dibuka melalui smartphone dan tablet, memungkinkan para guru menyiapkan dan menyajikan materi pembelajarannya secara online (dan offline) yang mudah diakses siswa.
\end{abstract}

Kata Kunci: Google Apps, Literasi Digital, Sekolah Dasar

\section{PENDAHULUAN}

Memasuki era industri 4.0 yang ditandai dengan pesatnya perkembangan teknologi informasi memberikan dampak melimpahnya berbagai sumber daya informasi yang diperoleh secara digital tanpa batas. Sebagaimana kehidupan para generasi milenial saat ini yang hampir seluruh aspek kehidupannya mengandalkan era digital, atau dikenal dengan istilah digital native. Kondisi seperti ini juga tak heran memberikan perubahan perilaku siswa dalam memanfaatkan dan mengelola informasi. Keragaman bentuk dan tipe informasi seharusnya memberikan dampak positif dalam mendorong siswa agar lebih selektif dan mampu memaksimalkan penggunaan teknologi informasi.

Mersepon kemajuan teknologi informasi yang begitu pesat tersebut, salah satu organisasi internasional bidang pendidikan yaitu UNESCO memploklamirkan slogan literacy for all meningkatkan kualitas hidup diberbagai lini kehidupan baik secara 


\section{Pemanfaatan Google Apps di Era Literasi Digital \\ Pada Siswa Sekolah Dasar}

individu, keluarga ataupun masyarakat dengan harapan akan memberikan multiplier effect dalam sebagai upaya pemberantasan kemiskinan, pengurangan angka kematian pada kelahiran, penghambat pertumbuhan penduduk, pencapaian kesetaraan gender, pembangunan berkelanjutan dan perdamaian (Unesco, 2014).

Literasi merupakan hak asasi manusia dan dasar untuk belajar sepanjang hayat, yang mencakup berbagai aspek kehidupan, Secara makna, literasi diartikan sebagai seperangkat kompetensi dalam membaca, menulis, dan berhitung hal ini senada dengan pernyataan Faizah (2016:2) yang mengatakan bahwa literasi merupakan kemampuan mengaksesdan memahami secara cerdas aktivitas membaca, melihat, menyimak, menulis atau berbicara. Di sisi lain Widodo (2015:60) menambahkan bahwa pada kelas tinggi kompetensi literasi memberikan penekanan pada siswa agar mampu melakukan analisis kritis, seperti wawancara, observasi dan menulis laporan. Dari pernyataan tersebut maka dapat disimpulkan bahwa fokus literasi yang dimaksud adalah kemampuan membaca dan menulis.

Literasi merupakan jantung kemampuan siswa untuk belajar di sekolah. Oleh karena itulah untuk menghadapi tantangan zaman dan teknologi informasi maka pada kurikulum 2013 dibentuklah gerakan literasi sekolah yang menempatkan siswa sebagai subyek dalam belajar, bukan obyek. Tugas guru, lebih bersifat sebagai penyedia pengalaman belajar (fasilitator). Guru tidak lagi diposisikan sebagai satusatunya sumber belajar, tetapi hanya sebagai salah satu dari semua sumber belajar yang bisa digunakan siswa. Pembelajaran dalam kurikulum 2013 menuntut siswa untuk aktif, mulai dari melokalisir sumber informasi yang diperlukan, memilah dan memilih informasi sesuai dengan kebutuhan, dan memproses dengan nalar dan pikirannya agar diperoleh kesimpulan dan keputusan yang diperlukan. Tujuan penelitian ini untuk mendeskripsikan pemanfaatan Google Apps di era literasi digital pada siswa Sekolah Dasar.

\section{METODE PENELITIAN}

Metode penelitian menggunakan penelitian deskriptif kualitatif dengan teknik pengumpulan data menggunakan studi kepustakaan teknik simak, dimana salah satu tekniksimak adalah teknik catat. Teknik catat merupakan teknik pengumpulan datadengan cara menggunakan buku-buku,literatur ataupun bahan pustaka, kemudian mencatat atau mengutip pendapat para ahli yang ada di dalam buku tersebut untuk memperkuat landasan teori dalam penulisan artikel ilmiah.

\section{HASIL DAN PEMBAHASAN}

\section{A. Kemampuan Literasi}

Literasi merupakan keterampilan yang dibutuhkan seseorang berkaitan dengan membaca dan menulis (UNESCO, 2006). Kirsch, I. S., Jungeblut, A., Jenkins, L., \& 
Kolstad, A (1993:2-3) berpendapat bahwa literasi adalah “ kemampuan menggunakan informasi cetak dan tertulis dalam masyarakat, untuk mencapai tujuan seseorang serta mengembangkan pengetahuan dan potensi seseorang". Definisi ini merupakan pengembangan dari definsi The National Literacy Act di Amerika Serikat tahun 1991 yang mendefinisikan literasi sebagai “.... kemampuan individu untuk membaca, menulis, dan berbicara serta menghitung dan memecahkan masalah dalam tingkat lebih tinggi yang berfungsi dalam dunia pekerjaan dan masyarakat, untuk mencapai tujuan seseorang, mengembangkan pengetahuan dan potensi seseorang” (Irwin, 1991).

Menurut Viruru (2003) yang berangkat dari perspektif postkolonial, membagi makna literacy menjadi empat, yakni: (1) literacy as entity (berdiri sendiri serta berada di luar kontrol manusia secara individu maupun lingkup masyarakat); (2) literacy as self (literasi adalah sesuatu dibentuk atau terjadi secara personal) (3) literacy as institution (literasi layaknya mata uang yang bisa bertambah, berkurang, dan menjadi indikator kesuksesan) dan (4) literacy as practice (literasi adalah fenomena aktivitas berbagai manusia yang mengkomparasikan beberapa literasi).

Stokes (2008) juga memberikan empat makna pada istilah literasi. Pertama, literasi adalah kemampuan seseorang untuk membaca dan menulis. Kemampuan dasar ini merupakan prasyarat menuju interaksi sosial. Kedua, membaca, menulis, dan komputasi dalam derajat tertentu yangmemungkinkan individu berinteraksi dalam masyarakat yang kompleks. Ketiga, literasi merujuk keseperangkat kemampuan yang lebih tinggi yang memungkinkan seseorang berpartisipasi penuh dalamsistem sosial, ekonomi, dan politik. Keempat, literasi merupakan karakteristik kelompok sosial ataukelompok budaya tertentu. Seperti bahasa, literasi adalah variasi praktik-praktik budaya yang dimiliki beragam entitas sosial.

Literasi merupakan keterampilan yang sangat mendukung dalam proses pembelajaran. Apabila literasi siswa rendah, pada kebanyakan kasus, mengakibatkan rendahnya pemahamannya terhadap suatu objek (Geske \& Ozola, 2008).Sebagian besar proses pendidikan bergantung pada kemampuan dan kesadaran literasi. Budaya literasi yang tertanam dalam diri siswa akan mempengaruhi tingkat keberhasilan baik di sekolah maupun dalam kehidupan bermasyarakat.

\section{B. Literasi Media Digital}

Literasi media menurut Baran \& Denis dalam Tamburaka (2013), merupakan suatu rangkaian gerakan melek media, yaitu: gerakan melek media dirancang utuk meningkatkan kontrol individu terhadap media yang mereka gunakan untuk mengirim dan menerima pesan. Melek media dilihat sebagai ketrampilan yang dapat dikembangkan dan berada dalam sebuah rangkaian dimana kita tidak melek media dalam semua situasi, setiap waktu dan terhadap semua media. Berdasarkan 


\section{Pemanfaatan Google Apps di Era Literasi Digital \\ Pada Siswa Sekolah Dasar}

pernyataan tersebut dapat diketahui bahwa literasi media merupakan suatu upaya yang dilakukan individu supaya mereka sadar terhadap berbagai bentuk pesan yang disampaikan oleh media, serta berguna dalam proses menganalisa dari berbagai sudut pandang kebenaran, memahami, mengevaluasi dan juga menggunakan media.

Istilah literasi digital pertama kali diungkapkan Gilster (1997) bahwa literasi digital merupakan kemampuan penggunaan teknologi informasi dari perangkat digital secara efektif efisien dalam berbagai konteks kehidupan sehari-hari. Bawden (2001) memperluas pemahaman literasi digital yang berasal dari literasi perangkat komputer dan informasi. Literasi komputer berkembang pada dekade 1980-an ketika komputer mikro semakin luas dipergunakan, tidak hanya di lingkungan bisnis, tetapi juga masyarakat. Sementara itu, literasi informasi menyebar luas pada dekade 1990-an manakala informasi semakin mudah disusun, diakses, dan disebarluaskan melalui teknologi informasi berjejaring. Martin (2006:155) merumuskan definisi literasi digital adalah kesadaran, sikap, dan kemampuan individu untuk menggunakan alat dan fasilitas digital secara tepat untuk mengidentifikasi, mengakses, mengelola, mengintegrasikan, mengevaluasi, menganalisis, dan menyintesis sumber daya digital, membangun pengetahuan baru, menciptakan ekspresi media, dan berkomunikasi dengan orang lain, di konteks situasi kehidupan tertentu, untuk memungkinkan tindakan sosial yang konstruktif; dan merenungkan prosesnya.

Hague (2010:2) mengemukakan bahwa literasi digital merupakan kemampuan membuat serta berbagi dalam keadaan dan bentuk yang berbeda dalam rangka berkolaborasi, dan berkomunikasi secara lebih efektif, serta memahami bagaimana dan kapan teknologi digital digunakan dengan baik dalam menciptakan proses tersebut. Dengan demikian, dapat disimpulkan bahwa karakteristik literasi digital tidak hanyamengacu pada keterampilan operasi dan menggunakan berbagai perangkat teknologi informasi dan komunikasi teknologi (perangkat keras dan platform perangkat lunak), tetapi juga untuk proses "membaca" dan "memahami" sajian isi perangkat teknologi serta proses "menciptakan" dan "menulis" menjadi sebuah pengetahuan baru.

Penelitian Martin \& Grudziecki (2008:3) melalui hasil penelitian mereka, keterampilan literasi digital ditekankan pada sikap dan kesadaran seseorang dalam mengggunakan perangkat ICT untuk berkomunikasi, kemampuan berekspresi dalam kegiatan sosial, dengan maksud untuk mencapaitujuan pada berbagai situasi kehidupan individu yang bersangkutan. Kemampuan literasi digital akan menjadi lebih baik, bila mampu dikembangkan dalam situasi kehidupan yang nyata, serta mampu memecahkan masalah. Kemampuan literasi digital menjadikan seseorang mampu mentranformasikan kegiatan melalui penggunaan perangkat teknologi digital. Setiap orang harus memiliki kesadaran sebagai orang-orang yang melek digital, dalam konteks kehidupan, pekerjaan maupun belajar. Penyelesaian masalah dalam kehidupan sehari-hari menjadi hal penting bagi generasi digital natives melalui 
penguasaan literasi digital. Penyelesaian masalah kehidupan termasuk, penyelesaian tugas-tugas sekolah (Kenton \& Blummer, 2010:84).

Kompetensi literasi digital ditinjau pada aspek berpikir kritis, dikemukakan (Meyers, Ingrid,Ruth, 2013:355) aspek berpikir kritis dalam literasi digital sangat penting, karena beragamnya informasi di internet, dan kemudahan konten informasi diciptakan pengguna internet. Keterampilan literasi digital sebagai pengembangan berpikir, artinya kesadaran berpikir terhadap tugas-tugas yang dibebankan kepada seseorang. Cara berpikir kritis seharusnya menjadi bagianpenting dalam mengembangkan tahapan literasi informasi pada level mengevaluasi informasi secara kritis.

Hari ini kendala terbesar dalam menciptakan suasana literasi di sekolah sebenarnya berasal dari internal sekolah, di antaranya kemampuan guru dan sarana prasarana sekolah yang berhubungan dengan literasi masih kurang memadai, kebijakan tentang program literasi yang belum dirumuskan secara tertulis, serta tidak ada program literasi digital di perpustakaan sekolah, sehingga siswa tidak terlatih dalam mencari, menelusuri, mengolah, dan mengevaluasi informasi secara efektif dan efisien. tingkat literasi di kalangan siswa juga berdampak budaya menjiplak yang sering terjadi di lingkungan sekolah. Oleh sebab itu, guru beserta segala komponen yang ada didsekolah harus memiliki keterampilan literasi informasi yang baik agar dapat mengajarkan keterampilan literasi informasi kepada para siswa

Disisi lain keterampilan literasi media digital ini sangat penting sebagaimana Baran (2010:24) menyatakan bahwa kemampuan dan keahlian kita sangat penting dalam proses komunikasi massa. Kemampuan ini tidak selalu mudah untuk dikuasai (ini lebih sulit dari sekedar menyalakan komputer, menayangkan televisi atau membalikan halaman majalah kesenangan anda) tetapi ini sangat penting dipelajari dan dapat dilakukan. Kemampuan ini adalah literasi media (media literacy) kemampuan yang secara efektif dan efesien memahami dan menggunakan berbagai bentuk komunikasi yang bermedia.

Selain itu pula adapun keterampilan literasi media memiliki beberapa tujuan diantaranya adalah sebagai berikut:

1. Bertujuan membantu konsumen agar memiliki pengetahuan dan pemahaman yang cukup tentang isi media, sehingga dapat mengendalikan pengaruh media dalam kehidupannya.

2. Untuk melindungi konsumen yang rentan dan lemah terhadap dampak media penetrasi budaya media baru.

3. Tujuan literasi media adalah untuk menghasilkan warga masyarakat yang "well informed" serta dapat membuat penilaian terhadap content media berdasarkan pengetahuan dan pemahaman mereka terhadap media yang bersangkutan. 


\section{Pemanfaatan Google Apps di Era Literasi Digital \\ Pada Siswa Sekolah Dasar}

\section{Media Google Apps for Education}

Google Apps adalah layanan berbasis aplikasi yang diciptakan dibuat oleh google. Menurut perwakilan Google, Sundar Pichai, Google Apps memungkinkan pengguna mengunggah dan mengakses berbagai file seperti video, foto, spreadsheet dan PDF. GoogleApps dapat diakses dari mana saja. Di rumah, kantor, atau bahkan saat berada jauh dari perangkat yang kita miliki. Dengan aplikasi tersebut dapat digunakan di komputer Mac dan merek lain. Selain itu, juga bisa digunakan di komputer tablet dan ponsel bersistem operasi Android. Tidak hanya itu, pengguna yang mengalami gangguan penglihatan pun dapat mengakses dan menggunakan alat pembaca layar (screen reader). Google Apps memiliki aplikasi google drive denga kapasitas penyimpanan sebesar 5 Gigabite (GB) dan dapat digunakan gratis. Google dengan layanan tersebut dapat memfasilitasi penggunanya untuk berkolaborasi, membuat, menyimpan dan membagi dokumen dengan pengguna lainnya. Adanya layanan manajemen dokumen online oleh Google memberikan kemanfaatan yang besar untuk dunia pendidikan.

\section{Google Apps for Education terdiri dari:}

1. Gmail: Akun email untuk masing-masing siswa, pengajar, staff dengan banyak fasilitas yang disediakan dan fungsi yang sama seperti akun gmail Reguler dengan kapasitas penyimpanan hingga $20 \mathrm{~GB}$, sehingga membantu siswa dalam menyimpan dan mencari informasi dengan cepat dan mudah.

2. Google Calendar: Siswa dapat mengorganisir rencana kegiatan dan acara-acara yang kemudian bisa di share kepada yang lain.

3. Google Talk: Siswa dapat memanggil dan mengirim pesan pada yang lainnya setiap saat, dari manapun di muka bumi ini.

4. Google Docs: Siswa dapat berbagi file dokumen, mengerjakan sebuah dokumen secara bersama-sama dengan kelompok dalam 1 sekolah dan hasilnya dapat di publikasikan kepada orang banyak.

5. Google Sites: Luncurkan Sebuah website untuk kelas, tim, atau sebuah projek dengan mudah.

6. Google Drive: Layanan yang terkoneksi langsung dengan google docs, jadi anda bisa berbagi file dalam waktu yang sama.

7. Google Classroom: Suatu serambi pembelajaran campuran yang diperuntukkan terhadap setiap ruang lingkup pendidikan yang dimaksudkan untuk menemukan jalan keluar atas kesulitan dalam membuat, membagikan dan menggolonggolongkan setiap penugasan tanpa kertas.

Menurut Khikmawati (2015) dukungan fitur yang dimiliki google Apps membuat layanan yang satu ini mempunyai peluang potensi yang sangat besar untuk dunia pendidikan, diantaranya adalah:

1. Untuk proses belajar mengajar

Guru dapat melakukan kegiatan belajar mengajar di kelas melalui google Apps dengan cara-cara diantaranya seperti berikut:

a. Siswa diberikan bahan tayang (atau semacam video), kemudian siswa diminta 


\section{Ulum B., Fantiro F.A., \& Rifa'i M.N. / LENTERA Jurnal Ilmiah Kependidikan Vol. 14 No.2 (2019) 22 - 31}

untuk mempelajari secara mandiri dan siswa diminta untuk memberikan tanggapan berupa pertanyaan atau pernyataan.

b. Guru memberikan topik pelajaran dan siswa diminta untuk memberikan respon baik pertanyaan maupun pernyataan yang sesuai, sehingga terjadi diskusi yang interaktif. Sesama siswa dapat saling memberikan pendapatnya. Dari respon siswa yang masuk guru dapat memberikan penilaian terhadap keaktifan siswa maupun kualitas pendapat siswa.

2. Merekam aktivitas siswa

Google Apps dapat digunakan untuk merekam aktivitas siswa di kelas, diantaranya adalah merekam kehadiran, nilai, dan aktivitas siswa. Guru dapat memanfaatkan spreadsheet yang ada di Google Drive untuk merekam kehadiran dan nilai peserta. Untuk melacak aktivitas siswa, guru dapat memberikan tugas, sehingga dari tugas tersebut dapat terlihat bagaimana kreativitas, keaktifan/peran serta, dan pendapat siswa.

3. Evaluasi Belajar

Google Apps dapat digunakan untuk melakukan evaluasi pendidikan, diantaranya evaluasi belajar. Guru dapat melakukan evaluasi dengan cara membuat kuis online dan kemudian memberikan penilaian secara otomatis menggunakan Google Formatau Google Classroom

4. Kerja tim

Google Apps sangat mendukung untuk kerja tim menggunakan spreadsheet google. Dimana guru dapat memberikan tugas yang dikerjakan secara tim dan siswa yang tergabung dalam tim tersebut, bisa mengakses dan mengedit pada dokumen yang sama secara bersamaan. Dengan demikian siswa terlatih untuk bekerja dalam tim.

5. Merangsang kreativitas siswa

Melalui Google Apps guru terlatih untuk memberikan pendapatnya. Hal ini dapat merangsang kreativitas siswa, di mana siswa dapat bebas mengutarakan ide dan gagasannya. Selain itu siswa juga belajar dari ide orang lain dan belajar memahami pendapat orang lain.

6. Dengan layanan pengolah kata/Dokumen,

Google Apps memfasilitasi penggunanya untuk membuat berbagai dokumen, baik dokumen berupa naskah umum ataupun naskah yang ditujukan untuk kebutuhankebutuhan khusus, misalnya untuk pembelajaran matematika. Pengolah kata pada Google Apps juga bisa digunakan untuk menuliskan rumus atau symbol.

7. Layanan Presentasi memberikan fasilitas pengguna untuk membuat file-file presentasi untuk pendidikan ataupun pembelajaran di kelas.

8. Spreadsheet yang dimiliki Google Apps secara fungsi hampir sama dengan pada aplikasi perkantoran lainnya. Spreadsheet pada Google Apps juga bisa 


\section{Pemanfaatan Google Apps di Era Literasi Digital \\ Pada Siswa Sekolah Dasar}

dimanfaatkan untuk pembelajaran, diantaranya untuk evaluasi belajar, survey pendidikan, model-model pembelajaran.

9. Layanan gambar memberikan kesempatan pengguna Google Apps untuk membuat objek yang bisa dimanfaatkan untuk pembelajaran. Misalnya membuat objek matematika berupa bidang datar, bangun ruang, dll.

10. Layanan google form memungkinkan seseorang untuk membuat formulirformulir untuk kepentingan pendidikan

Dengan memanfaatkan Google Apps dalam dunia pendikdikan khususnya pembelajaran di kelas, memungkinkan para guru menyiapkan dan menyajikan materi pembelajarannya secara online (dan offline) yang mudah diakses siswa. Guru dapat mengunggah materi pembelajarannya dalam berbagai bentuk dan format seperti dokumen, audio, video, dan sebagainya. Materi-materi tersebut dapat dilihat secara langsung atau diunduh melalui smartphone, tablet, dan/atau komputer siswa. Di samping itu, pemanfaatan peralatan seperti smartphone dan tablet mempuyai banyak keuntungan, di antaranya mudah dibawa kemana saja (portable), lebih terjangkau (harganya) dibanding dengan komputer, memberikan kesempatan belajar tanpa batasan ruang, mudah untuk akses informasi melalui nirkabel, mendorong pengembangan literasi digital, memberikan kesempatan belajar dengan bebas (independent learning). Google Apps memfasilitasi penggunanya untuk melakukan pembelajaran yang kreatif, kolaboratif, eksploratif, dan mengoptimalkan kemajuan teknologi informasi (Khikmawati, 2014).

\section{SIMPULAN DAN SARAN}

\section{A. Simpulan}

Literasi digital merupakan kemampuan-kemampuan penggunaan teknologi informasi dari perangkat digital secara efektif efisien dalam berbagai konteks kehidupan sehari-hari, literasi digital tidak bisa dianggap sebelah mata dalam merespon kemajuan teknologi di era indiustri 4.0, mengingat siswa sekolah dasar hari ini merupakan generasi milenial yang disebut dengan digital native. Salah satu upaya literasi digital adalah pemanfaatan teknologi informasi menggunakan Google Appsfor education yang telah disediakan oleh perusahaan mesin pencari google untuk segenap komponen pendidikan di sekolah.

Dengan memanfaatkan Google Apps dalam proses pembelajaran yang dapat dibuka memalui smartphone dan tablet, memungkinkan para guru menyiapkan dan menyajikan materi pembelajarannya secara online (dan offline) yang mudah diakses siswa. Guru dapat mengunggah materi pembelajarannya dalam berbagai bentuk dan format seperti dokumen, audio, video, dan sebagainya. Materi-materi tersebut dapat dilihat secara langsung atau diunduh melalui smartphone, tablet, dan/atau komputer siswa. Di samping itu, pemanfaatan peralatan seperti smartphone dan tablet mempuyai banyak keuntungan, diantaranya mudah dibawa kemana saja (portable), 
lebih terjangkau (harganya) dibanding dengan komputer, memberikan kesempatan belajar tanpa batasan ruang, mudah untuk akses informasi melalui nirkabel, mendorong pengembangan literasi digital

\section{B. Saran}

Sekolah perlu mengadakan berbagai kegiatan literasi digital untuk menyonsong revolusi industri 4.0 dan segera berbenah untuk mengejar kondisi dunia yang sangat dinamis dimana internet menjadi bagian dari kehidupan dengan harapan besar agar terwujud generasi milenial baik itu peserta didik maupun guru di lingkungan sekolah yang literate terhadap budaya membaca, menulis, mengolah, dan mengevaluasi segala informasi pada era digital.

Selain itu pula perlu adanya pengawasan dan pengarahan yang ketat dan penuh dengan kehati-hatian untuk sekolah dan keluarga agar nantinya peserta didik tidak mengarah pada aktivitas literasi yang memiliki dampak negatif serta penggunaan device dan gadget secara berlebihan sehingga menimbulkan kecanduan.

\section{DAFTAR RUJUKAN}

Baran, Stanley J. (2010). Pengantar Komunikasi Massa: Literasi Media dan Budaya. Jakarta: Salemba Humanika.

Bawden, D. (2001). "Information and Digital Literacy: A Review of Concepts". Journal of Documentation,

GeskeAndrejs, Ozola Antra (2008). Factors influencing reading literacy at theprimary school level. Problems Of Education In The 21stCentury Volume 6

Gilster, P. (1997). Digital Literacy. New York: Wiley.

Hague, Cassie dan Sarah Payton. (2010). Digital Literacy Across the Curriculum: a Futurelab. Handbook. 2017 United Kingdom" dalam https://www.nfer.ac.uk/publications/FUTL06/FUTL06.pdf, diakses pada 27 September 2018.

Irwin, P. M. (1991). National Literacy Act of 1991: Major Provisions of P.L. 102-73. CRS Report for Congress. Washington, D.C: Library of Congress, Washington, D.C. Congressional Research Service.

Khikmawati, M.N. (2014). Google Drive Untuk Pendidikan. P4TK Matematika. Yoyakarta

Kirsch, I. S., Jungeblut, A., Jenkins, L., \& Kolstad, A. (1993). Adult literacy in America: A first look at the results of the national adult literacy survey. Washington DC: US Department of Education, National Center for Education Statistics. 


\section{Pemanfaatan Google Apps di Era Literasi Digital Pada Siswa Sekolah Dasar}

Martin, A. (2006). Literacies for Age Digital Age" dalam Martin \& D. Madigan (eds),Digital Literacies for Learning. London: Facet.

Martin, A., \& Grudziecki, J. (2006). DigEuLit: concepts and tools for digital literacy development. Innovation in Teaching and Learning in Information and Computer Sciences.

Meyers, E.M., Ingrid, E., \& Ruth, V.S. (2013). Digital literacy and informal learning environments:an introduction. Learning, Media and Technology.

Kentonon, J., Blummer, B. (2010). Promoting digital literacy skills: examples from the literature andimplications for academic librarians. Community \& Junior College Librarie.

Stokes, W. (2008). Literacy. In N. J. Salkind \& K. Rasmussen (Eds.), Encyclopedia of Educational Psychology (Vol. 2, pp. 608-616). CHAP, Thousand Oaks, CA: SAGE Publications. Retrieved from http: // go. Gale group. com/ps/i.do?id = GALE\%7CCX2660600171\&v=2.1\&u=idpnri\&it=r\&p=GVRL\&sw=w\&asid=d 98f1b290ec93e722610044b3c52e496.

UNESCO. (2006). Understandings of literacy. Retrieved 2015, from http://www.unesco.org/education/GMR2006/full/chapt6_eng.pdf

UNESCO. (2014). Literacy for All. (Online). (http://en.unesco.org/themes/literacyall, diakses 24 September 2018).

Viruru, R. (2003). Postcolonial Perspectives on Childhood and Literacy. In Handbook of Early Childhood Literacy (pp. 13-22). ELEC, SAGEPublication Ltd. http://doi.org/http://dx.doi.org/10.4135/9781848608207.Diakses pada 24 September 2018.

Widodo, Slamet dkk. (2015). Membangun Kelas Literat Berbasis PendidikanLingkungan Hidup Untuk Melatihkan Kemampuan Literasi Siswa Di SekolahDasar. Prosding Seminar Nasional Pendidikan. Diakses pada 24 September 2018. 